\title{
Exploring Orientation in Remaking High School Readers' Literacies and Identities
}

\author{
LesLey A. ReX \\ 2022 School of Education, University of Michigan, 619 E. University, \\ Ann Arbor, MI 48105-1259, USA
}

\begin{abstract}
In taking as its focus classroom instructional discourse, this study builds upon a program of research into the academic literacy practices of a classroom for "gifted and talented" students that successfully integrated "general college preparatory" students. The study applies aspects of Bourdieu's concept of habitus and Gee's theory of socioliteracy to observe "principles" in the teacher's pedagogical discourses. By describing three dominant "orienting" discourses in relation to a student's responses and performances, the analysis demonstrates concordances between the teacher's and the student's principles. The implications of these concordances for thinking about detracking or destreaming of students and teachers are considered.
\end{abstract}

At the end of the school year, all of the students in an English class designated for "gifted and talented" students, when asked what they had learned about reading and writing, referred specifically to their classroom motto. The motto's importance and ubiquity was expressed by a student as

Take notes on anything odd, inappropriate, confusing, or boring. It's probably important. If something kind of sounds out of place or confusing ... right off, you should probably write it down because it has a deeper meaning. I've found that to be true. (Kora)

\footnotetext{
is A version of this paper was originally presented as part of a symposium-Classroom discourse and social identity: Ethnographic perspectives-at the International Association of Applied Linguistics 12th Congress of Applied Linguistics, Tokyo, 1999.
}

Direct all correspondence to: Lesley A. Rex, 2022 School of Education, University of Michigan, 619 E. University, Ann Arbor, MI 48105-1259, USA. E-mail: rex@umich.edu 
Kora had not begun the year thinking about reading and writing in this way. For the first time in her schooling, she had self-selected into the English "gifted and talented" track from the "general college prep" track because she considered it her only chance to learn what she needed to make it into a "decent" university. In the course she transformed from reading and writing like a "general college prep" student to performing like a "gifted and talented" one. In prior studies, I extensively explored this transformation (Rex, 2001) and described the kinds of reading practices that she was able to perform (Rex \& McEachen, 1999). I was interested in understanding how a student with no prior experience in the academically rigorous literacy practices being asked for came to read and write in the same performance range as students who had been practicing them for years. In a series of linked studies (Rex, 1997; Rex, Green, \& Dixon, 1997; Rex \& McEachen, 1999; Rex, 2001; Rex, Murnen, Hobbs, \& McEachen, in press), I explored how Kora's successful "remaking" was a sociocultural creation, in part influenced by discourses the teacher invoked. The classroom's discursive practices positioned general students to perform like gifted students, while gifted students were positioned to engage collaboratively with the general students in performing intellectually challenging academic literacies.

In this study, I continue my interest in understanding the shaping influence of Kora's teacher's discourses. In previous studies (Rex \& McEachen, 1999; Rex, 2001; Rex et al., in press), I theorized that her teacher's instructional discourses served as "orienting discourses." In a classroom culture, where student accomplishment and status were evaluated by how well students lived up to the performance expectations of the group, orienting discourses provided principles for what was expected. Orienting discourses provided a means for all students to become members in good standing of their evolving discursive culture as they built norms for literate activity. However, they were especially important for less acculturated students, like Kora. The general college prep students required more opportunities to orient to what was expected, to learn how to achieve those expectations, and for their more accomplished peers to orient to "their achievements." The relatively quick and successful integration of the two groups in this classroom raised the question driving the study: What role did the orienting discourses play in the general students' successful academic performances?

\section{ORIGINS OF THE STUDY}

\section{Role of The Researcher}

The call of scholars (e.g., Lather, 2001; Veroff \& Destephano, 2002) for educational researchers to position themselves in their studies, and to reflect upon how their histories predispose them to conceptualize and interact in the construction of the phenomena they research, leads me to include my personal history as 
part of this study. I am aware that my story about my history has influenced the focus of this program of research, the particular orientation I take toward doing it, and the interpretations I make from it. I entered the US public school system as an immigrant from a working class London family at the age of ten. My father and mother's moves to sustain a viable family income led to my attending five elementary schools in two countries and to amassing a troubled academic and social record. My father had left school at 13 and my mother at 16, and though they promoted education neither had the time, energy, or resources to do more than insist that I do well in school. It is not an exaggeration to say that though I could satisfactorily read and write, I did not do so outside of school. In school, my checkered performance was driven by my initial belief that school knowledge had little to do with real life, that I was smarter elsewhere where it counted, and that my father's strict punishment would be visited upon a poor performance. However, by the time I entered high school, I had determined that an education-although I had a naive view of what that meant-was the only ticket out of my narrow life. The 1960s optimistic zeitgeist, a strong economy, Sputnik, a massive infusion of funds into US public education, and teachers who knew what to do with the money changed my academic life. In ninth grade English, I was reading Plato's Republic (we had a class set), dressing in bed sheet togas, and as philosopher king debating the relative influence of determinism and free will.

Looking back from my current position as a member of the academy, I am aware more than ever of how personal, social, economic, and political events converged to produce opportune conditions for my academic engagement and development. I am also cognizant of the importance of conditions within the elite track high school classrooms I inhabited. For a nonreader, who found more personal meaning in schoolyard scuffles and detentions in the principal's office than in being a good student, to come to value Greek philosophy raises unresolved questions for me. On the one hand, my schooling achievement is a testament to good teaching and powerful curriculum. On the other, I am dissatisfied with the lack of theory and descriptive insights into how the personal, social, and academic come to be successfully negotiated. We have considerable literature about what low achieving students need to be academically successful, but precious little that shows us what is at work when they are.

My subsequent 20 years as a high school and university English teacher and 15 years as an English teacher educator have reinforced my interest in researching classroom practices that promote integration and the learning of literacies that give all students access to society's opportunities and goods. This experiential narrative influenced my choice of Kora as the subject of this study and shapes the continuing story I tell about her. In retrospect, I undoubtedly selected Kora from among the other "general college prep" students taking the class because in her initial interview she conveyed aspirations for "getting ahead" via education, concerns about her academic preparation, and dispositions toward accomplishment 
that I found resonant. When I understood how successfully she had learned her lessons, I directed my focus on Kora's teacher's classroom discourses in order to understand their role in what she had accomplished.

\section{Kora's Situation}

Kora's aspirations and achievements can be understood within the context of the conditions of her family, of her schooling experiences, and of the literacy knowledge she coveted. Of the 21 ninth grade English classes taught at Kora's high school the year of the study, six were designated for "gifted and talented" students (hereafter referred to as GATE as the track and students were referred to in the school) who were almost all European-American from upper middle class or professional class families, two thirds of whom had been designated GATE since elementary school. Their curriculum was characterized by reading numerous and lengthy texts from the traditional literary canon, engaging in regular analytical classroom discussions, and writing literary analysis essays.

Kora did not meet any of the criteria by which students were designated "gifted and talented." In contrast to GATE, Kora's general college prep classes were composed of the remaining students, 55 percent of whom were Hispanic, of which 22 percent were classified as Limited English Proficient and 68 percent qualified for free or reduced lunch. Many of her classmates' home literacy practices differed from school literacy, and Standard English was not the students' dominant social language. Kora's academic performances_-mostly A's and B's-were at the top of the wide range exhibited by her classmates, which encouraged her to think she was a capable student.

The college preparatory curriculum called upon her to read short, less demanding texts, to engage in academic activity of briefer duration that exercised low order knowledge retrieval and reporting than the GATE classes. Opportunities for writing about or discussing texts were limited, and inquiry was rare. Considerable attention in her courses was directed to managing and correcting what was viewed as nonstandard or outside of the range of acceptable behavior or academic performance. When Kora spoke about her academic preparation in her College Prep English classes, she voiced a view common among students and teachers. Her A grades for English represented something quite different from her GATE peers' As in terms of academic capital. She was convinced she would not be admitted to the college of her choice if she stayed in the College Prep track.

Kora lived with her mother (a college graduate) and recently arrived stepfather, a lawyer. She had always thought she would go to college, had been a "good" student, and had found the conditions instigated by her mother's divorce, single parenting, and remarriage unsettling but not disruptive of her schooling, although; she noted that for several years while her mother worked, she did her homework alone. She expressed appreciation for her mother's renewed engagement in her 
schooling and her stepfather's mentoring about the academic demands of college. She attributed her interest in improving her academic knowledge to what she had learned from him.

\section{HABITUS AND SOCIOLITERACY}

\section{Habitus and a Theory of Principled Action}

In conceptualizing how my perspective has influenced this study and how Kora integrated into the new order of academic literacy practices, I have drawn from Bourdieu's (1977) theory of "habitus"- - which he conceives as a set of deeply internalized master dispositions that generate action. Bourdieu's theory is that action is practical, pre-reflective, durable though adaptive, reproductive though generative and inventive, and the product of particular social conditions though transposable to others (Swartz, 1997, p. 101) Actors are not rule followers or norm obeyers, but strategic improvisers who respond dispositionally to the opportunities and constraints offered by various situations (Swartz, 1997, p. 100). Although interpretrations of Bourdieu's early work emphasized social reproduction, especially as an expression of class values, his later work, is more attentive to the principles underlying social materiality, and directs us away from the material structures themselves to see what inspires actors to construct them. Bourdieu refined his definition of habitus to

a system of durable, transposable dispositions, structured structures predisposed to function as structuring structures, that is principles which generate and organize practices and representations that can be objectively adapted to their outcomes without presupposing a conscious aiming at ends or an express mastery of the operations necessary in order to attain them (Bourdieu, 1990h, p. 53) (the italics are mine for emphasis).

Applying this lens to Kora's classroom led me to theorize that the students and the teacher brought to the learning enterprise ways of being, habitual states, predispositions, tendencies, propensities, or inclinations that were common to the members of their same group or class, and which were produced by the material conditions of their prior existence. The "general college prep" students brought their notions of what it means to "do English" and to be a successful English student, as did the GATE students. These reflected the values, beliefs and dispositions of their families and primary social groups and social classes as well as their schooling institutions. Their habitus functioned as sets of principles for them to generate and regulate what they considered "regular" social-academic practices within their newly formed class. Kora's middle class familial and social codes directed her to act in certain ways and to assess the actions of her teacher and classmates according to value-based, principled criteria. Because her personal habitus was 
not monolithic or unidimensional, she could affiliate with her teacher and classmates when she recognized her own principles in their discourses, what Bourdieu refers to as "objective homogenizing" (Bourdieu, 1977). In other words, the initial teaching-learning interactional activity of their classroom involved students trying on and assessing the principles of the practices mobilized by their teacher. Over time, as principles are repeatedly acknowledged and recognized by the students as matching their world view and aspirations, classroom practices coordinated and a common code or set of criteria for good practice was agreed upon.

Such objective homogenizing and affiliation is complicated and difficult to achieve among members of groups with widely divergent habitus, but less so when members have more in common. This is because during instructional activity, individual class members rely on their habitus principles to respond to unforeseen and ever-changing teaching and learning situations. As they respond they either affiliate or distance themselves from the activity and establish their identities as literate or divergent practitioners. The larger the number of common principles shared by class members, the more easily and confidently students recognize "regular" reactions and perform "regular" strategic actions.

These relations operate automatically and invisibly, and are accomplished without consciousness or deliberate intention. This theory of principled action to achieve learning and group affiliation, as Kora's accomplishment demonstrated, required her full attention and hard work and considerable homogeneity of principles so that she could regard the activity they informed as necessary, sensible, and attainable. It required that Kora and her similarly successful classmates make the literate activities (e.g., reading, making a case, and assessment) their own. They needed to recognize what they were being asked to perform as situated objectifications of the principles they already held. When they did, they repeated what they perceived as a necessary complicated academic practice until they developed expected competence.

\section{Socioliteracy and a Theory of Discursive Identity Positioning}

James Gee's (1996) theorization of socioliteracy adds a discursive dimension to this action theory of principle-driven learning. He posits how classroom student selves are social perspectives or positions created through discourses that produce and reproduce opportunities for people to be and recognize certain kinds of people. This process is accomplished through the relationship between local discourses and macro societal discourses. Local discourses, with a small d, are "connected stretches of language that make sense, like conversations [or] stories ...; they are a part of Discourses, marked with a capital D, which are ways of being in the world [as] sort[s] of identity kit[s] which come complete with the appropriate costume[s] and instructions on how to act, talk, and often write, so as to take on a particular social role that others will recognize" (p. 127). For the students in Kora's 
classroom to be able to engage in their discourses of learning, compatibility had to have existed between the social Discourses of society that spoke through the local discourses of the teacher and the Discourses of the students as they engaged in the instructional conversations. According to Gee's perspective,

Discourses ... are always ways of displaying (through words, actions, values, and beliefs) membership in a particular social group or social network, people who associate with each other around a common set of interests, goals, and activities. A Discourse, then is composed of ways of talking, listening (often, too, reading and writing), acting, interacting, believing, valuing, and using tools and objects in particular settings at specific times, so as to display and recognize a particular social identity (Gee, 1996, p. 128). (Italics added)

In addition, Gee refers to Bourdieu and Foucault to conceptualize

Discourses create 'social positions' (perspectives) from which people are 'invited' ('summoned') to speak, listen, act, read and write, think, feel, believe and value in certain characteristic, historically recognizable ways, combined with their own individual style and creativity (Gee, 1996, p. 128).

The combined principles-based theory of action offered by Bourdieu and the identity positioning theory of socioliteracy presented by Gee provide a frame for studying the teacher initiated discourses that became commonly acted upon by Kora and her classmates. Earlier studies (Rex \& McEachen, 1999; Rex, 2001) indicated that Kora's and other students' talk and writing displayed their construction of social membership and literate status over the first 30 days of class. They also determined that instruction was dominated by teacher led classroom discussion. Of 1,670 instructional minutes in the first 30 days, 1,216 were occupied by teacher initiated and led discussions with whole class or with small groups while the class observed. These studies led me to hypothesize that the extent to which the teacher made particular classroom discourses possible strongly influenced social membership, position, and literate performance. Through their ubiquity, the teachers' discourses influenced which other discourses would be produced, and therefore who would produce them; how they would be judged, and therefore who would experience social and academic approval. In this way, the teacher's discourses determined which principles would become orienting principles, and thus determined the field of potential engagement for individual students.

\section{ORIENTING DISCOURSES AND THE STUDY QUESTIONS}

In another previous study of Kora's classroom practices (Rex \& McEachen, 1999), I observed that orienting discourses worked in two ways to orient and shape student literacy and identity construction. They served a maintenance purpose. 
By maintenance I mean they guided students in the building and sustaining of common expectations for what counted as literate performance, and in the building and sustaining of individual understanding of appropriate subjectivities (who to be) and voices (how to say). I illustrated that a common set of principles for who could say or do what with whom for what purposes under what conditions and with what outcomes were objectified through the discourses, and sustained through repeated, over time intertextual (Bloome \& Egan-Robertson, 1993) and intercontextual (Floriani, 1993) references to them.

One example of the maintenance function of a discourse, or of the rule it established governing social participation and academic engagement, was that students and the teacher could poke fun at prior classroom activity but not at individual students. In fact, making fun of an activity was used frequently to undercut tense situations and save face for students. A GATE student invoked this maintenance discourse to deflect attention away from Kora when she gave a misreading. Cognizant that a pattern of making fun of the archaic language had been established, Bobbie asked what the word "shitten" meant, and the resulting interchange quickly shifted attention away from Kora.

Another purpose for orienting discourses was realized in Kora's classroom. Orienting discourses supported transience. They allowed Kora and her classmates to acknowledge and affirm the evolution of common expectations, to incorporate divergent literacy performances, and to acknowledge and affirm individual experimentation with subject positions and voicings. By permitting experimentation, change, and divergence within a range of principled practices and performances, discourses of transience guided transformation of prior academic and social ways of acting and being. Rachel's (another general college prep student) question illustrates a transient function at work. The teacher had overheard Rachel asking her question of her neighbor and asked her to bring it to the attention of the class. She asked, "Are we supposed to think that somehow Beowulf like he has a deeper understanding of everything?" The teacher commented to the class "That's an interesting point, isn't it?" And then later, after Rachel elaborated her thinking behind the question, he said, "Pretty good. Pretty good thinking. Just to raise the question shows some pretty good thinking there." He continued by admitting that he had not thought of her question and asked two GATE students who often spoke up whether they had. Each confessed they hadn't and the teacher concluded with "... it shows a greater depth of consciousness here that I think may be supported by other parts of the poem. That's very interesting." This discourse works to bring in a voice rarely heard in the discussions (a general student's), to validate the intellectual quality of the contribution (the question), and to provide another dimension of textual analysis (a new reading).

Studying the ways in which orienting discourses work can forward our understanding of classroom integration and learning. When teaching and learning is observed as a gradual process of emergent social acts within an evolving culture of 
expectations, what is expected and accomplished is transient, and norms for performance evolve. Therefore, discourses of orientation provide recognizable principles for participation by which students act in response to unforeseen and ever-changing situations. Students' acts are recognizable as orienting actions when they are acknowledged, valued, and taken up by the collective (Bloome \& Egan-Robertson, 1993). When students take these discursive actions, novel, mediating transformative interactions can occur to remake how they are viewed and what they can do. They can replace ways of reading and writing they are used to with new practices. For a student like Kora whose integration was fraught with risky and uniformed decisions, orienting discourses became essential texts for deciding when and how to act.

\section{KORA'S RESPONSES}

Limited space permits only a brief summary of Kora's responses to the teachers' discourses to illustrate the social and academic dimensions of her orientation to achievement. The following excerpts are taken from the fully elaborated studies referred to previously. More extensive excerpts appear later.

Kora began the class with resolve to do well and the belief that she would learn because she had a good teacher. On her first essay, after reading the teacher's note that directed her to revise extensively by exploring the "so what" of her thesis, Kora responded, "I don't understand the concept of "so what!" HELP!! Her perception that she would learn what she needed as the class progressed is evident in other responses. Earlier, on her second reading quiz for which she earned an F, Kora had written about a Beowulf character, "I could never forget good old Thrith. And I didn't forget it because I didn't read it. I tried really I did but it was 11:00 p.m. and my eyes started to kind of drift shut. I couldn't help it." Kora's message to her teacher indicates her belief that he will be understanding and patient with her as she accommodates to the challenging reading load. This belief was reinforced on the 16th day of class when, during a discussion of a Canterbury Tale, Kora publicly misread as literal a Christian figure of speech. She thought the priest's "flock" was an actual herd of sheep, rather than his congregation. The teacher and another student tempered her public humiliation after she responded, "Is that wonderful... I can't get through these complicated analogies." Later, Kora's performance became more socioliterate as she demonstrated that she could complete the extensive reading load, understand the dense language, and make interpretive cases for her own reading. On her fourth reading quiz she responded to the prompt, "Make a case for one pilgrim being the most evil." She wrote, "I think that the Friar is the most evil of the pilgrims. He is in a holy profession and instead of using the trust he is given to help people he uses it to swindle money out of poor people. He hears confessions, and gives gifts and the like only because he expects payment. He is a crooked clergyman if I ever saw one." 


\section{THREE ORIENTING DISCOURSES}

Among the many influential discourses in Kora's classroom, three orienting discourses continued to exert their power throughout the duration of the year-long course and into her Advanced Placement Senior English class. One was the class motto, displayed prominently at the front of the room on the chalkboard, and written by each student on the front of his or her learning log. Every reading of and writing about the literature was oriented by this motto: "If anything is odd or inappropriate or confusing or boring, it's probably important." Class members used this motto to guide them to areas of the text upon which they would focus to prompt discussion, study, and illumination. The teacher's monologue, on Day 5, in which he laid out the reasons for the motto, referred to students' tendencies to skip over the impenetrable or boring bits of text as they read. He wanted them "to invest enough energy into these tricky little places [to] find out what is going on."

Another orienting discourse- "making a case"-was the term used to describe the logical means by which readers were to make a reading. The teacher never used direct teaching to instruct students in this logic. Rather, from the first day's reading he modeled, directed, and expected cases for readings in the interactive class discussions of text that he led. Readers were to find places in the text they thought were "probably important," figure out the probable importance of these pieces of text and make a reasoned reading supported by evidence from the text. To make their cases, students had to form a hypothesis that related their claim to a piece of evidence, and pieces of evidence to each other in a convincing chain. For example, if a student found a section that seemed inappropriate, he or she would generate a hypothesis as to why that might be. The hypothesis would have to be directly related to the specific section of troublesome text. Next, the student would formulate a claim (a thesis) in response to the hypothesis. This claim would have to be related to another piece of text that seemed to provide evidence for the claim. Next the reader would be required to find other pieces of related textual evidence with sufficient explanation of their relevance and arrange them in an order that built a persuasive case for the claim.

The third orienting discourse was the teacher's favorite object lesson story, one he told on the 13th day of class. This narrative was one of 68 object lesson narratives he told during the first 10 days of the course. It is a story he tells each year to introduce his method of grading student essays. The story of the dancer, like most of his stories, establishes his and his students' roles as well as the place of academics in students' lives. The story is imbued with meaningful representations of the teacher as a demanding but caring father figure, students as talented but in need of critical attention to push them toward achievement, and academic achievement as the route to success in the world. The story conveys the message that students who willingly seek to be criticized by their teachers will advance along an upward trajectory of advancement and success. 


\section{METHODS AND METHODOLOGY}

This study builds off of a program of research begun in 1993. A dissertation and 12 formal studies have emerged from a continually growing corpus of data and analyses. While data collection methods remained constant across all the studies, methods of transcription and analysis and logics of inquiry were adapted to suit each study's research questions. The following description provides a general summary of the approaches and methods I used. Please refer to the specific studies for more detailed explanations.

I had observed the teacher's classroom and most of the other English teachers' classrooms in Kora's high school for 6 years prior to the teacher becoming my co-researcher in the actual study. In my ethnographic role as participant-observer, the year of the study (Spradley, 1979, 1980), I lived in the classroom for the first 30 days and re-entered weekly throughout the remainder of the school year. In the classroom, I video taped all activity, collected all artifacts the teacher and students produced, and took field notes while participating as an observer-participant. In addition, I informally and formally interviewed all the students and the teacher throughout the year, followed up with selected students (including Kora) after they left high school and attended university, and gathered all institutional data on the students' academic performance (e.g., grades, test scores).

I followed a constant comparative interpretive method (inspired by Erickson, 1986; Strauss \& Corbin, 1990) for data collection and analysis so that questions guiding what to observe and how to view its importance evolved as the study proceeded. I met regularly with the teacher to triangulate my interpretations and re-entered the classroom to share transcripts and analyses with students. After all data were collected, I used structuration mapping to represent all discourse events, and I transcribed selected events (Green \& Wallat, 1981).

In transcribing the discourse events I followed methods pioneered by sociolinguists and classroom literacy researchers, for example, Bloome and Bailey (1992), Bloome and Egan-Robertson (1993), Gee and Green (1998), Green and Dixon (1993); and, members of the Santa Barbara Classroom Discourse Group (1992). I selected for analysis discourse events that informed relationships between the classroom's collective resources and individual teaching and learning performances. To observe what meaning was constructed for interactants within individual interactions, I performed semantic analyses of message units using the contextualization cue analysis developed by Gumperz (1992). I determined the meaning of particular discourses as they were taken up by class members over time by using Spradley's (1980) method of semantic analysis (wherein X is a kind of Y). In analyzing the teacher's discursive narratives, I held to the perspective that stories are symbolic conversational texts belonging to a culture (Geertz, 1973; Goodenough, 1981), constructed through dialogue, which compel as well as construct and convey transformation through the valenced constructions tellers make 
of themselves, others, and "realities" (Bakhtin, 1981). I looked to see how each narrative was a way of constructing knowing, the known, and the knower (White, 1981; Bruner, 1986).

For this study, I reanalyzed the three orienting discourses to specifically surface the principles they embodied. The two questions driving analysis of the three orienting discourses for this study ask (1) what were the meaningful principles represented in the three discourses?; and, (2) how did those principles and the discourse practices through which they were conveyed shape the literacy practices and the identities of the students?

\section{THE PRINCIPLES REPRESENTED IN THE THREE ORIENTING DISCOURSES}

\section{The Class Motto: "If anything [in your reading] is odd or inappropriate or confusing or boring, it's probably important" so make it the focus of your attention}

On the fifth day of instruction, the teacher asked the class if he had talked to them yet about the slogan that had been written on the front chalkboard since the first day of class. The students informed him he had not. For the next four minutes, as students wrote the motto in a prominent place in their learning logs"preferably the cover," the teacher explained what he meant by the motto. He began by locating its origin in an article by Elaine Hansen in a college book on how to teach Beowulf. Locating it in a college text lent the motto valuable academic currencythis is the way you will be expected to think in college. Such a tie makes textual and contextual links from the teacher's intellectual past to the students' academic present to individual student's collegiate futures.

The teacher said he would "be explaining quite a bit about that as we go through the year, and you are going to see that it's really a good thing to keep in mind whenever you are reading and writing about something that you have read." In making these statements, he framed a purpose for his explanation of the way of reading signified by the motto. In giving the explanation, the teacher made an argument for why the way of thinking in the motto is necessary and valuable for readers and writers of challenging texts. By appealing to what he described as students' common experiences of reading literature in school, the teacher told them how students should think as they read. Students who can recognize themselves in his description of reading can use the motto as a place to stand, from which they can orient more effective readings. They can locate the actions of their reading from the reference positions of oddity, inappropriateness, confusion, or boredom.

The following analyses foreground the discursive moves the teacher made in his explanation to the students and seven principles for reading and being a good reader those moves constructed. He described a "generic" good reader with whom 
he expected all of his students to identify; he noted that all good readers are sometimes wrong; he attributed wrong readings to the capriciousness of the mind's attention, and described how the mind deals with difficult textual passages. Having established what readers - even good ones-do to avoid difficulty, he argued for why they should make it the focus of their attention. He acknowledged this kind of reading may result in occasional boredom; nevertheless, as a group and as individual readers they would focus on the difficult textual "nuggets" to reach their goal-understanding.

The teacher began by identifying all of the class members, including himself, as "good" readers and by describing an active, participatory process that he implied they all go through. In his use of "we" and "you" throughout his monologue, the teacher constructs a single reading role and reading process with which he expects all students to identify. This is the first principle: we are all good readers and we all read by making hypotheses about meanings as we actively interact with text.

As the good readers that we are, we are continually and actively engaging the text. I talked a little bit about, you know, what we bring to that reading experience-just all our personalities our intelligences our vocabularies, just all of these things that we are bringing to the reading experience. Well as we begin to read, we start to hypothesize, "Oh, this must be about such and such." You may not even be consciously aware that you are doing this. But a good reader is actively hypothesizing and getting feedback... getting, you know, interpreting words, revising hypotheses, working through the passage. That's what makes you an active attentive reader. It's that you are participating with it.

Kora agreed with the teacher that she was a good reader. In her prior classes she had often been one of the best readers by engaging in the text the way her teachers expected. She also agreed that she was not consciously aware of what she had been doing.

The teacher continued his explanation by pointing out the vagaries of the reading process. Again, he talked collectively about the "likeliest" experience of readers-they will make wrong guesses about what the text means. By describing error-maker as an inevitable facet of the good reader's identity the teacher introduced a second fundamental principle for reading in this classroom.

Unless the reading is so obvious and so just prosaic that you ... just commonplace, that it doesn't have a new thought in it, the likeliest thing is that as you go through hypothesizing you will be wrong about what it was about. You know. You are making guesses and those guesses aren't quite right. They are a little off because this is taking you in somewhat surprising directions. (2-second pause.) That's how you learn from reading because it doesn't just tell you something you already knew. So you revise your hypotheses. 
Kora was no stranger to guessing. She thought students who were better readers than she did not guess, and she was pleasantly surprised to learn that they do.

At this point in his explanation, the teacher provided a cognitive reason for readers' incorrect guesses- the tendency of the mind to shift the focus of its attention from place to place and subject to subject. This move establishes a third principle - all good readers have active minds that jump among multiple focal points, which inevitably makes reading a difficult enterprise because it requires disciplined attention.

What happens too is while... just even right at this moment, even though as I look around it does look like you are paying attention. I also know that our minds are in the room, out of the room, in the room, over to some other person, back to me, thinking of tonight, back to me, thinking of the book, how much homework do I have, back to me. Isn't that how the minds work? That's how they work while you read too. So this crazy, you know, capricious mind that we have is attending a lot of the time, not nearly all the time. And so sometimes when we have our hypothesis, and we seem to be validating it, we'll be reading along and we'll realize this doesn't make sense. This doesn't seem even relevant to my ... my, you know. You don't put it in these words, but you go, "What?" And why it's a "what" is because it's not consistent with your hypotheses.

One of Kora's repeated complaints was her inability to sustain a focus. She confided that this was one of her major hurdles in doing well in the class. That all good readers have this problem she found comforting.

Next, the teacher enlarged upon what happens when the readers' active minds encounter words and passages that they don't understand. They may skip them and go ahead to passages that do make sense. This fourth principle recognizes avoidance as a key reading strategy in the making of meaning from text.

There's several things that can happen when you go, "I don't really get this." The most common thing is to skip over it and continue not to get it. That's the most common thing hands down. Ninety percent most common I would guess. You just skip over it. That's what happens in a little tiny way when you see a word you don't know ... just don't even know you've skipped it. And when you get into a passage that doesn't quite match, and then, and then you get beyond it and you go, "Oh yeah, Oh yeah.” And you are back to your hypotheses and revising.

Kora was no stranger to skipping the dull or hard parts. She had learned how to "read" a text without reading all of it, by relying on what the teacher said about the text in class.

At this point, the teacher began his argument for why such natural tendencies of readers need to be attended to in a particular way. He laid the groundwork for the way of thinking he wanted students to practice as they read and wrote about 
texts. They were to resist the tendency to skip odd, inappropriate, confusing, or boring passages. Instead, they were to make them the focus of their attention, to regard them as places that might yield insights of import. This fifth principle is key. By making this move, not only did the teacher require that students reverse their minds' natural and habitual tendencies, but also he asserted that they are all capable of making the reversal.

But there are these places where it didn't make sense to you. Well, often that's where the author is saying something surprising, or, you know, just very unorthodox, something that you had no expectation of at all. And it maybe the most important part. (1-second pause.) It may be the pivotal part of this essay or narrative passage or description or whatever it is that you are reading. And what I want to help you develop is more a sense not that (he stops)

The teacher interrupted his explanation to acknowledge their common experience of boredom as they read difficult passages. He provides a sixth principleboredom is merely an expression of lack of understanding. By using his Basic English Skills students as an illustration, many of whom are learning English as a second language, the teacher means to argue for the universality of the experience. Invoking the comparison of the "good" to the "basic" readers also lends thrust to the argument the teacher was making. Basic students cannot read Beowulf (and comparable difficult texts) because the text would have too many difficult places and they would get too bored. However, good readers (like themselves) can deal with the boredom they encounter.

And one reason that you know that you are not understanding, too, is that it is boring to you. If you are reading and you get bored, then probably the reason is 'cause you are not following it. And it's boring to read words that you can't follow. That's what happens. You know, if I had my basic English skills class reading Beowulf, they would just get so bored with it because it would be hard for them to follow it. So that is something that we each experience, sometimes for a few seconds, for a minute, or the evening with reading. If we just aren't really following it, we think we are but we're really not. It doesn't make sense. We get bored.

The teacher's reference to basic readers had particular resonance for Kora. She had experienced the differences between her reading and the lower performances of her previous classmates. She recognized in the reference her own strengths as a reader. Afterall, she had found prior readings more understandable and had been able to tolerate the boredom more efficaciously than basic readers.

The teacher told the students what they would do to deal with the boredom brought on by lack of understanding. They would be giving those places "a little extra attention," enough to make them understandable. By making the assertions he did, the teacher provided another key principle. He knew all the students could read 
and understand the texts, so he expected all of them to give the readings sufficient time, energy, and focused attention to reach the point of "real" understanding. In other words, principle number seven: reading should be hard work.

Kora, who believed the reading demands teachers had made in other classes had been too simple and easy, welcomed this opportunity. The chance to develop understandings of difficult texts had been one of her main reasons for selecting this class.

\begin{abstract}
We want to start looking for these little places. These are the nuggets. These are where we are going to find answers to questions we might ask in essays ... uhm .... Maybe even most significant messages in the work will be from places that we might initially have just skipped over because they didn't seem consistent with any hypothesis we've made and we're sort of maybe not paying attention then or whatever. We just skip it. So what we are going to try to do is find those places and give them a little extra attention. Okay? Uhm, we won't do things like this. We won't pass our eyes over all the words and dream that we have read something if we really didn't understand it. That's silly isn't it. If I say I read it but I didn't understand it and I'm capable of reading it, then what is the truth of it? Mr. I read it. I just didn't give it enough attention to understand it." That's the truth of it, isn't it really? So we are going to try to invest enough energy into these tricky little places so we can find out what's going on and that will help us a lot. That will be an important dimension in our research for papers. Okay?
\end{abstract}

Kora respected expenditure of energy. As a volleyball player, she liked to train hard. She was looking forward to paying attention and working and believed that this teacher could show her what to attend to.

In his presentation of the class motto, the teacher provided a principled way of thinking and proceeding for the reading and writing students would do over the next 175 days. He also implied that thinking in this way would serve them academically in their later schooling experiences, information he knew was of interest to the students in this classroom, which was Kora's purpose for being in the class.

This way of thinking served as a cognitive procedure for individual student readers and writers to construct "regular" versions of readings. The motto also provided the teacher's expectations for how regular, appropriate, or "right" versions would be constructed and established his agenda for collaborative practice. Cooperatively, they would recognize difficulties and take time to overcome them.

In actual practice over the course of its first 30 days, the class as a group came to a common understanding of a group recognized textual encumbrance on only two occasions. Nevertheless, on each occasion the class read together and on recurrent occasions for writing, teacher and students identified and explored difficult textual places in keeping with the motto and making-a-case thinking. How often students engaged in such activity outside of class was not in the scope of this study to explore. 
However, students' reading logs and their essays documented their engagement in "motto thinking" as individual readers and writers. As they read at home, they were guided by the motto to record what was noteworthy in the text; and, when they were composing their essays, they followed the procedures for "making-a-case," the literate practice directly related to "motto thinking."

To ensure opportunities for motto thinking practice, the teacher explicitly invoked it during class readings in the weeks after introducing it. The motto became a way of thinking implicit in conventional classroom practices. Outside of class, what students found odd, inappropriate, confusing, or boring framed discussions, readings, and writings. In class during readings, students asked questions about confusing segments of texts, and the teacher engaged them in thinking about the text in ways that supported their learning to make cases for their own readings. As Kora's comment at the beginning of this article demonstrates, the motto became her guide for how she read and what she noted for further reflection and application. She took it with her into her next year's Advanced Placement English class where she earned a B and an A with the same teacher.

In the following excerpt from my interview with her after a month in the class, Kora explains her initial expectations. She describes her shift as a reader and writer from "spitting back what the teacher wanted to hear" to "think[ing] things out" when she writes because her teacher values her opinion.

I: So I'm wondering if what you expected coming in and if, if you found what you expected to be true?

$\mathrm{K}$ : Um, well I expected this class to be, um, harder than the regular classes from what I'd heard from older people that already taken classes.

I: Okay. Harder in what way?

$\mathrm{K}$ : Um, just that maybe you had to like use, use your mind more. Um, maybe not necessarily but I don't know. Because that, my ah, my 9th grade English class and my 10th grade English class were not very. English has never been; it's always been my favorite subject so it hasn't been really that, you know. I mean sometimes, but not, for like tests and stuff. But I like writing essays you know, and I like push myself to the point of exhaustion but I like doing it, you know. It's not like math for me. I can't stand that. I just do it, you know, to do it, but English I like English. So when I thought, the class I, I never really thought my expectations are. You know I heard that Mr. was a great teacher and so I was excited. I tried to get this teacher because I like English so much so I. About hardness-like I, hardness really isn't my object. For my other English classes it's sorta like I really haven't feel like I've learned all that much. Um, I've just sort of like spit back what the teacher wants to hear; like what the teacher's opinions are I have to like put that in my essay and I don't like having to do that, but I don't know, it just seems like. 
I: Did you expect that this class would be like that when you came in?

$\mathrm{K}$ : Um, well I guess I've been doing that like all my, all my years. I mean the difference for me and like another student writing an essay would be, I mean, I've, I'm a little more, I guess I try do what like other people don't. So it, you know, if everyone else goes with the teacher, what the teacher thinks, or what the teacher wants then I try to do something else. But I still try to like to stick those guidelines. So I guess I've always done that so maybe when I was going into the class I didn't really know any different. But I mean now, I can see that, I don't know, he, he values you know someone's opinion.

I: Oh, so that it is different than what you expected?

$\mathrm{K}$ : A little, but since I heard that he was such a good teacher, I figured that any good teacher would have to value someone's opinion.

I: Oh, okay. So that was already

$\mathrm{K}$ : [Yeah.

I: [a value that you had?

K: Yeah.

I: So do you, does he, is your sense right now that he does value your opinion?

K: Yeah.

L: Yeah.

$\mathrm{K}$ : I think so. But I think it'll make me a better writer because then I'll have to think about those things and I usually don't, you know, think things out.

Kora indicates that she valued engagement in motto directed reading even more now that it had been explained to her and she had had opportunities to practice it.

\section{Making a Case: How to Make a Reading From a Textual Dilemma}

Besides selecting a difficult place in the text to focus on, students were expected to make meaningful understandings of these textual opacities and argue for their understandings. They were expected to make cases for their readings, although making a case as a persuasive logic was not explicitly named except in discourse about the essays they were writing to present their readings. The teacher, in his almost daily discursive interactions with the class about the text, led them through case making for readings - through generating a hypothesis, then providing a convincing chain of textual evidence that could transform their hypothesis into a valid claim-by engaging their current level of understanding of the process. How the teacher's discursive interactions with students shaped the students' take up of this reading practice is visible in the following excerpt from the classroom discourse on the day after he explained the motto. 
While passing out paper in preparation for a reading quiz, the teacher overheard students talking about a confusing use of two names in the tale they had read. He took advantage of this interaction as a way to collaboratively practice and affirm the motto thinking students were doing. He delayed the quiz, and brought the issue to the floor of the classroom. Then later, in response to a student question, he initiated the case-making logic of inquiry. Table 1 presents a transcript of the first moments of the interaction.

A right answer had been given, but the lesson did not end there. As represented in Table 2, a "gifted" student asked, "How are you supposed to know that." His tone suggests his question had several meanings. He was asking specifically how the teacher and AR determined that Arcete and Arceta were the same person. He was voicing frustration with his position as someone who does not read in this way. He was also asking for guidance in how the teacher and AR made that reading so that he could do it too. The teacher responded with a brief answer that served to justify more than explain his reading. He did not respond to the student's voiced frustration. In fact, the tone of his answer bordered on the dismissive: “... who

Table 1. A Textual Dilemma

\begin{tabular}{|c|c|c|}
\hline & Speaker & \\
\hline 1 & $\mathrm{RC}$ & Why did Arcete... \\
\hline 2 & LB & Why did it change to Arceta \\
\hline 3 & MS & Yeah. Why did they keep changing it? It's really confusing \\
\hline 4 & $\mathrm{~T}$ & $\begin{array}{l}\text { (Said to RC.LB and MS) That is interesting. (Said to the class) Now I've } \\
\text { heard two people asking why Arcete becomes Arceta sometimes. So } \\
\text { before we have our quiz let us look... we are going to do a little } \\
\text { detective work here. Let us see if we can find some data. We're just } \\
\text { approaching this inductively. We're going to take a look at some data. } \\
\text { We've got Arcete and Arceta. If you look on page } 49 \text {, for example, it says } \\
\text { (He reads), "Now as he spoke Arceta chanced to see this lady as she } \\
\text { roamed there to and fro." It's Arceta there, right? Kay. Notice lower on } \\
\text { page } 49 \text { it says (He reads), "Now in good earnest said Arcete the best so } \\
\text { help me God I mean no jesting now" }\end{array}$ \\
\hline 5 & & Students talk \\
\hline 6 & $\mathrm{~T}$ & $\begin{array}{l}\text { Its funny isn't it. Now sometimes when something is odd, inappropriate, } \\
\text { confusing, or boring we know it to be... }\end{array}$ \\
\hline 7 & Students & (in chorus) Important \\
\hline 8 & $\mathrm{~T}$ & $\begin{array}{l}\text { Probably important. We may have such a thing here; we may not. But it's } \\
\text { certainly something 'cause it's, you know, on } 48 \text { (he reads the line). "And } \\
\text { at the cry Arceta gave a start and said, 'My cousin Palimon, what ails } \\
\text { you?" Any ideas }\end{array}$ \\
\hline 9 & Student & No \\
\hline 10 & $\mathrm{~T}$ & This is a little like missing the sand in the middle of the Sahara \\
\hline 11 & AR & Is this the same person \\
\hline 12 & $\mathrm{~T}$ & It is the same person \\
\hline
\end{tabular}


Table 2. A Textual Dilemma (Continued)

\begin{tabular}{|c|c|c|}
\hline & Speaker & \\
\hline 13 & Student & How are you supposed to know that \\
\hline 14 & $\mathrm{~T}$ & $\begin{array}{l}\text { Well, there are only two cousins Arceta and Palimon, and who would this } \\
\text { other person be? That wouldn't make sense, would it }\end{array}$ \\
\hline 15 & EL & $\begin{array}{l}\text { Could it be like a name he got when he was knighted. He had an official } \\
\text { name of Arcete for Arceta, or vice versa }\end{array}$ \\
\hline 16 & & $\begin{array}{l}\text { Arceta? OK. That's a good hypothesis. Could we ... check that out? Let's } \\
\text { look at page } 49 \text { and see if we could make that hypothesis make sense. On } \\
\text { page } 49 \text {, if, for example, Palimon called him Arcete, and so all the times } \\
\text { that he's Arcete it's in a quotation... but that the narrator calls him } \\
\text { Arceta. That, you know, or something like that might be evidence, right }\end{array}$ \\
\hline 17 & EL & Doesn't happen \\
\hline 18 & $\mathrm{~T}$ & $\begin{array}{l}\text { But we don't find that, do we. So... } \\
\text { Well, let's see. Is there any other page. There are lots of them. (He scans the text) }\end{array}$ \\
\hline 19 & $\mathrm{BE}$ & Forty-nine says Arcete \\
\hline 20 & $\mathrm{~T}$ & $\begin{array}{l}\text { Well, } 49 \text { we had .... (He reads the text) } \\
\text { OK now. On } 50 \text { we have Palimon in a quotation saying (he reads) "No } \\
\text { false Arcete that you shall never do" }\end{array}$ \\
\hline 21 & $\mathrm{BE}$ & Maybe \\
\hline 22 & & $\begin{array}{l}\text { We're on... we're just... we are looking at this mystery at this spelling } \\
\text { of Arcete and Arceta, trying to come up with a hypothesis. And I've } \\
\text { given you a clue. It's sort of like not noticing the sand in the middle of the } \\
\text { Sahara. And truly you might not. In fact, archeologists have only really in } \\
\text { the last } 10 \text { or } 15 \text { years started studying sand as a major source of } \\
\text { information about deserts, and that kind of thing. They study all sorts of } \\
\text { other elements of the desert, but not the sand. (Chuckle) }\end{array}$ \\
\hline
\end{tabular}

would this other person be? That wouldn't make sense, would it?" The student he was addressing did not respond. Conversely, when general student EL provided a hypothesis for the character's different names, the teacher moved to affirm her hypothesis and to lead the class in searching the text for evidence to test it.

One effect of these two moves was to position the first student and his question as inappropriate and to position the second as appropriate and reasonable. To the second student the teacher said, "That's a good hypothesis." Let's look at page 49 and see if we could make that hypothesis make sense." He directed students to see if there was consistency in who used the two versions of the name, and they found that there was not.

Another effect of these interactions was to validate hypothesis generation and evidence collection from the text as the first step after locating a textual difficulty. The interaction that proceeded from EL's tentative question became the first step in making a case.

The teacher led the students through a search for evidence for the validity of EL's hypothesis. Finding none, he waited for another forthcoming hypothesis. None was 
offered. Rather than providing his own answer to the dilemma of two names for the same character, he gave the students what he called "a clue" by reading a line of text containing the name. He also referred back to his Sahara desert analogy to provide an explanation for what was occurring. These two discourse moves are key in this teacher's approach (and students' orientation) to shaping the class's literacy strategies, in constructing the role students will take as readers, and in shaping their attitudes and beliefs about what they are doing.

The teacher refrained from providing definitive readings for the text. Additionally, once students had learned the rules for making readings in the classroom, on the occasions when he did forward his own reading, they demanded he make cases for them. By not providing a prima facie reading, he positioned students to produce the reading and to believe that, when substantiated, their readings were as valid as any he or authoritative readers could make. The classroom's rich texture of making a case discourses positioned students as detectives and reading as investigations full of mystery and red herrings.

By comparing the students to archaeological detectives who were focused on other desert elements before looking at sand, the teacher provided a principled explanation for why some readings can be made while others cannot-that is, kinds of readings depend upon what one chooses to observe. Later in the interaction, he followed up the analogy by referring students to another element of text they had observed in a previous class session-rhyme scheme. When they looked at the rhyme pattern for the lines containing the one syllable Arcete and two syllable Arceta, their function in the meter became visible and produced another way of solving the dilemma and reading the text. The principle was clear: If students could not solve the reading dilemma, the problem might be where they were looking. They were simply not focused on where they needed to be. In time, with plenty of looking at lots of elements, and plenty of case makings, they would be able to read, understand, and persuade others of the validity of their reading.

The following excerpt from Kora's first essay demonstrates her grasp of what counted as reading and as making a case for her own reading by the 18th day of the class. In this opening paragraph, she refers to the origination of her eventual thesis through a logic of absence and presence, and provides specific evidence from the text to warrant her assertions. She claims that Christ is not mentioned once in a poem written by a Christian author and that Beowulf, the main character, has many Christian qualities. He also has many pagan qualities. Following the thinking modeled by her teacher, Kora asks herself Why might the author deliberately blend Christian and pagan religions, and elicits her theory or hypothesis: The poem was a self-conscious instrument for conversion to Christianity. In the remainder of her essay, Kora made a flawed beginner's argument for her thesis. However, we already see in this first attempt an orientation toward text and case making that is clearly influenced by the classroom discourse set in motion by the teacher. 


\section{BEOWULF}

The author of Beowulf was supposedly Christian and yet in the whole poem Christ is not mentioned once. Is He not the basis of Christianity? Although God is mentioned often, Christ is not. The main character has many of the qualities one would expect to find in a Christ-figure. He is looked up to, he is strong, he is trustworthy, he takes the faults of others onto himself. "They have seen my great strength for themselves/Have watched me rise from the darkness of war/Dripping with my enemies' blood. I drove/Five great giants into chains." (lines 420-480)

He also has many qualities one might expect to find in a pagan hero. He is a great warrior, and he has much fame and riches; battles and fighting are very important to him. Beowulf looks to me like a deliberate blend of the two religions. My theory is that Beowulf was written to teach the pagan people about Christianity by making Beowulf someone that they could look up to.

\section{The Dancer: An Object Lesson for Understanding Criticism}

The essays and short answer quizzes students wrote as they engaged in motto and making a case thinking served as their assessment benchmarks. Each year, before returning the first set of essays, the teacher told a particular story to prepare students for his critical remarks. His narrative was a story within a story. He reported a tale told to him in the early days of his teaching by a former English student who was also a student of dance. His discourse created a particular identity for his former student and her dance teacher that can be read as an indication of the kind of teacher he wanted to be and of how he positioned his students.

When he began his story (on Day 13), the teacher signaled to students the historical weight behind the words and introduced his role as a patriarchal figure. His manner of introducing the narrative, "I want to tell you a little story," and his allusion to the timely coincidence of its original telling and the students' births served to initiate a fatherly theme that was reinforced throughout the narrative. For 17 years, while they had been growing up, he had been successfully guiding other students in this particular way.

\section{9:28-9:46:}

I want to tell you a little story. About 20 years ago-I can't believe it-actuallyno- probably seventeen —only seventeen. It was when you guys were born, about. I was teaching at LC Junior High and I had a student who was in my English class and also was my aide...

[Information removed about his relationship with aide and her family]

10:04-10:56: 
She came into the period when she was my aide, and I was teaching a class that period, and she seemed very down. And I said, well, what's the matter. And she said, well last night at ballet-This girl was really quite a fine dancer. In fact is a professional dancer in New York right now. Last night at ballet the teacher didn't yell at me. And I said, well, wouldn't that be more an occasion to rejoice than to be sad? And she said, well, no, not really, because he only yells at the dancers that he thinks really have talent, and that could get better. The kids that he knows, you know, they're just there, he doesn't yell at them, he doesn't give them a hard time, cause he knows they're sort of doing their best and sort of passes it off, and he usually yells at me and he didn't last night and I'm worried. And I said, well maybe he will yell at you tonight. So the next day she came back and she was her usual effervescent self, and in fact he had yelled at her and everything was OK again. And she went on to do a lot of solo dancing and chorus line dancing and major Broadway productions and continues as a professional dancer. (Day 13, GATE English Literature; 9:28-12:02)

The teacher's story depicted him as sensitive and student-centered. He was sensitive to his student's seeming "very down," and he took a lesson from her on how to be a good teacher. He did so because as the story told, she was talented, "really quite a fine dancer," who had become "a professional dancer in New York." By identifying the student in this way, the story held her up as a model of the excellent student. She had done so well in her dance classes that she was currently a professional dancer in a venue known for its fierce competition. The dance teacher was represented as the primary influence on the dancer's professional achievement. It was his "yelling" and giving of "a hard time" that somehow assured her success. Because he yelled, "she went on to do a lot of solo dancing and chorus line dancing and major Broadway productions."

The student's distress when she wasn't yelled at implies that she understood, accepted, and relied upon the master-apprentice relationship. For her, the teacher embodied the judgment she needed to succeed. The teacher's actions reflected that knowledge and were, therefore, in her best interest. Her distress also implied she hoped herself to be talented and promising in ways that her classmates who were not yelled at were not. She referred to these students as "just sort of there," "they're sort of doing their best" which wasn't good enough. In fact, it would never be good enough. They just didn't have what it takes. The indication that one has what it takes is that someone who knows what constitutes talent and promise yells at you to push you to make the most of it. When represented as a story told by a highly successful student, the story's message about achievement is that even students who are talented need to be continually pushed. For students listening to the story, it implied that if the teacher yelled at them they were talented, and they were fortunate to have a teacher who recognized that talent and pushed them.

The dancer's worry when the dance teacher stopped his pattern of yelling at her indicated another of the teacher's roles - to reassure students that they were 
actually as talented and capable of achievement as had been thought. This view of the teacher's purpose positioned students to regard their capabilities in terms of external reinforcements. As long as the teacher was yelling, the student thought she had more promise than others did. When the yelling stopped, doubt and insecurity immediately besieged her. Once yelling resumed, she was her "usual effervescent self." The teacher said, "in fact he had yelled at her and everything was ok again." The teacher's language represented this student's view of self as in need of external reassurance to insure its integration. That students who were talented and already viewed as promising and successful should rely upon and receive such support was presented as a given, reinforced by the story's happy ending.

The story provides many possible readings that can be construed as principles. Intertextual (Bloome \& Egan-Robertson, 1993) references to the story by class members, as well as the teacher's and students' discourse actions throughout the course suggest the following reading as most salient: Students should understand that some teachers will yell at them because those teachers believe that the students they yell at are talented and have promise. Teachers who care about their students' welfare and success need to maintain high standards and respond critically and regularly to their students' performances. A less evident reading of the story complicates the view reported by class members at the end of the term-that this was a collaborative community of learners. The story positioned students as competitors in the process of building and sustaining their identities in relationship to each other. The dancer viewed her success and her talent not only in relation to her teacher's yelling, but also in relation to her classmates' lesser performance. Some of her distress may have also been due to being treated as one of the kids who was "just there." In order to sustain the belief that she is better, she needed the teacher-who-yells-at-the-promising-students to yell at her. In order to continue to draw his attention and define herself this way, she was compelled to out perform her classmates. Yelling was not only a signal that she was talented and doing well; it also signaled social differentiation, that she was better than the others. This reading appears less complicated when we consider a difference in scale. Students in this class considered who they were in relationship to students within the larger school program. Students within English literature shared an identity, in contrast to students in the other English classes-like General English - who were being yelled at for reasons other than their academic accomplishments. The teacher's comments about the student papers that followed the telling of the story reinforced the positioning of the students and their work as exemplary and in keeping with the literacy purposes of schooling: "I would say, these are testimony to the value of a public school education, for one thing" (12:42-12:47). "They showed a sense of language, a kind of control, that was impressive" (12:54). "They reflected some good creative thinking" (13:30).

The teacher explicitly stated his purpose in telling the story when he began his explanation of his paper-grading approach. He asked students to keep the story in 
mind as they read the comments he had written on their papers: "That sort of has stayed with me, that little incident because ... I would like you to think about that when I write comments on your papers ..." (11:28-11:36). A little later during his explanation, he invoked the "yelling" metaphor from the story to describe what he was trying to accomplish through his comments: "So I was sort of saying good things and bad things and sort of "yelling" at you, OK?" (11:56-12:02). Over the duration of the course, whenever the teacher returned student papers, he reminded them of the dancer story.

"Yelling" as a key metaphor in the story poses multiple questions: What constituted yelling both in the dance studio and in the English literature classroom? What did the dancer mean when she said she was yelled at? What did the teacher mean when he said he would "yell" at students on their papers? And, what did students understand his yelling to mean? The common sense entailments of yelling are loud volume and strong, strident language. Ethnographic data indicates that the teacher never raised his voice in the classroom or used what might be regarded as strong, abrasive language. Which is to say, he never yelled either verbally or in writing. By choosing this particular term, he reflected his understanding of his students' position, their experience, and their emotions. The teacher's evaluative practices indicate that while he believed critique was important, he was aware that students were particularly sensitive to having their work evaluated. He believed students experienced most evaluative comments as being yelled at, and could experience benign comments as deeply wounding. His explanation to the class contained references to his concern for students' feelings: "If we left it at that [a grade with little or no comment], I think what I would face, after passing these back, would be a class of wounded students, for one thing, who wouldn't have a clear way to heal ... I hope none of you will feel wounded by this" (14:15-14:41). The teacher told a story in which the apparent antagonist turned out to be the good guy, and the weapon (i.e., yelling) was revealed as a powerful positive. The story confirms his belief that though students may feel they are being yelled at, they will value his yelling and see him as their advocate. This orienting story for teacher evaluation of student work powerfully communicated a complexly structured ideological frame for dealing with the feelings students experienced as they read the teacher's responses to their work.

A concordance between the principles in the teacher's story and Kora's view of herself and of the role of paternal critics was visible in the way she described her writing for the class. She expressed an anxiety-ridden ambivalence about her intelligence, and her actions implied the benefits of supportive "yelling." While she had taken the course because she believed herself capable of learning the more demanding curriculum, she often voiced a conflicted view of her capabilities. Her insecurity is evident in this excerpt from her explanation of why she had difficulty improving her first draft of the Beowulf essay her teacher and stepfather had similarly critiqued. 
K: Except that I needed more evidence. I needed more quotations but when I did the rewrite, I didn't have my book with me so I couldn't, um, find anymore quotations 'cause I found the quotations in Beowulf and then once I had that then I went to the Bible. But when I didn't have my Beowulf book, I couldn't start with Beowulf and then go to the Bible. So it was really hard.

I: Why is it that you didn't have your book?

$\mathrm{K}$ : I forgot to bring it.

I: Oh.

$\mathrm{K}$ : Left in my locker.

I: Too bad.

$\mathrm{K}$ : I'm intelligent but dumb.

Students' parents regularly participated as critical readers and editors of their children's writing. Students spoke with appreciation and annoyance about this relationship as is evident in Kora's responses to her stepfather's and her teacher's criticisms and guidance.

$\mathrm{K}$ : Cause in the rewrite he [the teacher] said that it was, it was good except, um, I needed more quotations. But I didn't have my book so I couldn't add the quotations and I didn't know what "so what" was so I'm hoping he's not going punish me. Um, I don't know.

I: Now did you do all this on your own or did you talk to other people while you were doing it or share your drafts with them or anything? Other than what you did in class.

K: Um, I showed my draft to my stepdad.

I: Uh hum.

K: But I didn't let him correct it.

I: What kind of $=$

$\mathrm{K}: \quad=$ He would go through and tear it apart.

I: Would he? What kind of response did he give?

$\mathrm{K}$ : Um, let me see if I can remember. Um, he said it was good but he didn't like the conclusion either. Cause this is the first one before I got the rewrite back and, um, cause he helped me find those quotations, you know, from the Bible

I: [Uh hum.

K: [and so he liked those. And, um, some of the points, you know the ones that I wrote more about he liked, but the ones that I wrote less about he wanted me to write more about, but I couldn't think of anything more to write.

I: Right. 
K: So that was kind of hard. Basically, I don't know. He, he probably thought the same as Mr.

K: And, um, but I didn't think I need more quotations cause I like to just think something and not think about actually backing it up.

I: Okay. So then he pointed out that you needed more quotations and that you might need, ending needed rewriting.

K: Uh hum.

I: And then when you got your comments back from Mr. he basically said the same thing.

K: Yeah.

L: Yeah. Sounds like your stepdad is a good person to show your drafts to then, huh?

K: Yeah. Except that he likes to tear them apart too.

\section{DISCUSSION AND IMPLICATIONS}

Kora and her general college prep classmates performed in concert with the expectations in their teacher's discourses, which dominated the formative days of the course, were compatible, consistent, and redundant throughout its duration, and interrelated instructional activities and assessment. The students' successful and prompt integration into the new reading and writing practices raised the question: How might they have been predisposed to the learning challenges? Or, stated differently: How did the teacher's instructional talk resonate positively for students?

To address these questions, I have represented three particularly dominant orienting discourses in terms of their contribution to the meaning of classroom activity and their positioning of students as readers, writers, and respondents to criticism. This representation was accomplished by analyzing the three discourses as expressions of principles of academic practice for generating specific kinds of conduct visible in students' responses. Selections from Kora's spoken and written texts in the first month of the course illustrated her resonance with these orienting discourses. Though the reading, writing, and assessment practices were new to her, I demonstrated that many of the principles on which they were based were concordant with those she brought with her.

The length of this article did not permit a richly detailed description of all students' responses. However, Kora's struggles to learn were comparable to her general college prep classmates in terms of academic performance on essays, quizzes, and other written work. By the first quarter report card marking, the students' range of performance overlapped with their GATE classmates as grades of $\mathrm{C}$ to $\mathrm{A}$. If, as other ethnographic data indicated, to this point the two groups of 
students had consistently experienced two different kinds of English curriculum and pedagogy, this outcome permits the speculation that these students might, like Kora, share sufficient concordance with the principles of their teacher's pedagogy. Working from the assumption that students respond effectively to unrecognizable teaching and learning situations when they share common life values and beliefs with their teacher and classmates, I hypothesize that it was the students' recognition of similar ways of being, states, predispositions, tendencies, propensities and inclinations that made possible their academic learning.

If this speculation has legs, then from my perspective it has important implications for thinking about efforts to integrate uninitiated students into classrooms with rigorous academics or to place teachers used to working with sorted high achieving students into detracked classes. It would seem that attention given to the curriculum and pedagogy needs to include the principles they communicate.

Using this study as a case in point, we should consider how the principles position some students for success and make that success more difficult for others. Motto discourses were seen to offer explicitly articulated principles which positioned students to think in ways about their texts and themselves that acknowledged mistakes, avoidance, and boredom and encouraged attention, hard work, and mining difficulties for "nuggets" of understanding. Motto and making-a-case discourses shaped a way of reading and thinking that constructed students as capable detectives seeking to solve the mystery of their own confusion or boredom. Their purpose was to deconstruct confusion by constructing a reading of the text that would provide an understanding of literary conventions, of the world and structures of the text, and of the kinds of information students needed to bring to a reading of literature.

Students were well positioned for success if they entered this English literature class already predisposed to these principles of practice. For example, if prior experience had led them to believe that they should resist the tendency to avoid difficulties and, instead, mine them for insights, they were positioned advantageously to follow the class motto. Whereas, students who had learned to manage the difficulties in school and life through other predispositions would be less well positioned. These students may have deep experiential reservoirs supporting their reasons for avoiding difficulties. They may regard being asked to find meaning in what is difficult as nonsensical, a waste of time, or perhaps detrimental to their learning. Instead these students might want information that would resolve the difficulties with reading texts they encounter. If their history had constructed them as poor readers they would want the knowledge that the teacher and students who are good readers already had. They would not be satisfied with talking through the reasons why something in the text was confusing and finding evidence for why it was there, but would prefer to construct a meaning for the text that made sense to them. They might ask, "What was going on in Mead Halls, and why was Beowulf so convinced that he could beat Grendel alone and through physical force without 
using armaments?" Students in the English literature class may have had different ways of reading and writing about literature when they entered, but they believed they were capable readers in ways that resonated with their teacher's description. Beowulf may have been difficult, but they were ready to take on faith that investigating unique and arcane textual obscurities was positively meaningful and would pay off.

In addition, the motto and making-a-case discourse principles reinforced a single approach to reading - a central consistent relationship between the reader, the world, and the structure of the text. That relationship could only be engaged in with others who shared a sufficiently common reading of the world in relation to the text. Only knowledge that informed a commonly built understanding of the text could be brought forward from personal experience and validated. In the teacher's, Kora's, and her stepfather's world the Bible was accessible and reasonable as potential evidence for a literary argument. Readings that went in other directions were not given a place in the classroom discourse. For example, the ways in which the text can be read as informing the world directly inhabited by students or the larger worlds constructed by other texts like newspapers, popular culture, or family history were not available. Beowulf's defeat of Grendel through brute strength - the yanking of his hand and arm from his shoulder-could have been compared to Luke Skywalker's heroics in Star Wars or to Keanu Reeve's character's exploits in the Matrix by students for whom the messages in those texts resonate. Students whose worlds were more in tune with, for example, intimidation, threat, or even the management of demanding personalities would read the text and what counts as resources for interpreting it differently. The principles communicated in the teacher's discourses do not position students with these reading resources to focus on admission to a good college as an available or high priority. Nor do they provide a means for students to believe the curriculum is accessible or important for achieving that goal. The accommodations students would need to make to succeed with this reading approach would ask them to reject what they regard as sensible and important in their world. It is a leap of faith much greater than Kora's.

Additionally, the principles governing being a teacher and a student were more amenable to students with a history of positive relationships with adult authority figures. The dancer story in its clear establishment of teacher and student roles as master-apprentice, the students as talented, and criticism as evidence of it, reinforced a sense of status and uniqueness students may have been seeking or already felt was their due. When students resonated positively with the story's principles, their ways of being and their inclinations were validated as appropriate-they were special. Because they were who they were and thought as they did they could succeed; and, they would be successful if they continued to believe and act in those ways. Their success in the course became further evidence of these beliefs. Students who were not predisposed to view adult knowledge and authority as 
monolithically would regard this view of patriarchal apprenticeship differently, and would not experience reinforcement of their status. They have learned to obtain their reinforcement from other sources and to suspect adult criticism. They might respect the power wielded by adults, but yelling takes on a different meaning for students who have a history of checkered accomplishment that lacks the steady positive assistance of an adult. Authoritative demands are more likely to inspire resistance for the sake of self-protection.

I offer the following observation from my position as one who has personally experienced and professionally studied the rewards and the drawbacks of pedagogical and curricula practices that successfully bring general college prep students into the fold previously reserved for the "gifted and talented?" Without taking away from Kora's and her teacher's hard work and accomplishments, it seems important to consider how what made that accomplishment possible positions other students so that it is more difficult for them to achieve similar status. Such positioning keeps in place perceptions that sustain meritocratic and deficit models of achievement. When students are successful in such classrooms, their success reinforces the "rightness" of those principles and practices in making that success possible. By the end of the course, the successful students of English literature and their teacher were convinced more than ever of the rightness and regularity of their own habitual states and ways of being. The teacher continued to use the same discourses each year he taught the course, and, later, students attributed their success in their college English courses to the values and ways of thinking developed in the intellectual learning community of their high school classroom. That means that in this school students who already share those principles continue to move ahead academically, to be seen as the bright deserving ones, and will pass those values on to their children.

If we consider that all academic literacy pedagogies and curricula K-12 are informed by the principles of their teachers, then we should consider how the instruction in the higher tracks hierarchically separates and sorts. To do so adds another dimension to detracking initiatives, to claims that some students are not prepared for moving into more rigorous curricula, and to well-meaning attempts to give all students the kind of rigorous academic education previously reserved for a few. What if Kora's case demonstrates that bringing general college prep students into classes initially reserved for gifted and talented students may reinforce rather that deconstruct the negative effects of hierarchical tracking. Such moves can create a larger subgroup of students who consider themselves deserving of academic privileges and who know how to attain and sustain them, while reinforcing a pool of students who are further removed from their share in schooling's academic capital, who remain in lower, less demanding tracks (a process already described by Oakes, 1985). For these students to be successful, their classrooms must be dominated not only by powerful pedagogies and rich curriculum, but by discourses with whose principles they can positively resonate. 
Acknowledgments: Part of the research presented in this report was funded by a grant from the Spencer Foundation. I wish to thank the foundation, Dave McEachen, and Tim Murnen for their assistance in this work.

\section{REFERENCES}

Bakhtin, M. M. (1981). In M. Holquist (Ed.), C. Emerson \& M. Holmquist (Trans.), The dialogic imagination: Four essays. Austin, TX: University of Texas.

Bloome, D., \& Egan-Robertson, A. (1993). The social construction of intertextuality in classroom reading and writing lessons. Reading Research Quarterly, 28(4), 305-333.

Bloome, D., \& Bailey, F. (1992). Studying language through events, particularity, intertextuality. In R. Beach, J. Green, M. Kamil, \& T. Shanahan (Eds.), Multidisciplinary perspectives on literacy research (pp. 181-210). Urbana, IL: National Conference for Research in English/National Council of Teachers of English.

Bourdieu, P. (1977). Outline of a theory of practice. Cambridge: Cambridge University Press.

Bruner, J. S. (1986). Actual minds, possible worlds. Cambridge, MA: Harvard University Press.

Erickson, F. (1986). Qualitative methods on research on teaching. In M. Wittrock (Ed.), Handbook of research on teaching (3rd ed.) (pp. 119-1611). New York: Macmillan.

Floriani, A. (1993). Negotiating what counts: Roles and relationships, texts and contexts, texts and contexts, content and meaning, content and meaning. Linguistics and Education, 5, 241-274.

Gee, J., \& Green, J. L. (1998). Discourse analysis, learning, and social practice: A methodological study. In D. Pearson \& A. Iran-Nejad (Eds.), Review of research in education: Vol. 23 (pp. 119-169). Washington, DC: American Educational Research Association.

Gee, J. (1996). Social linguistics and literacies: Ideology in discourses. London: Taylor and Francis.

Geertz, C. (1973). The interpretation of cultures. New York: Basic Books.

Goodenough, W. H. (1981). Culture, language, and society. Menlo Park, CA: Cummings.

Green, J. L., \& Dixon, C. D. (1993). Introduction to talking knowledge into being: Discursive and social practices in classrooms. Linguistics and Education, 5, 231-240.

Green, J. L., \& Wallat, C. (1981). Mapping instructional conversations-A sociolinguistic ethnography. In J. L. Green \& C. Wallat (Eds.), Ethnography and language in educational settings (pp. 161-205). Norwood, NJ: Ablex.

Gumperz, J. (1992). Contextualization and understanding. In A. Duranti \& C. Goodwin (Eds.), Rethinking context (pp. 229-252). New York: Cambridge University Press.

Lather, Patti (2001). Validity as an incitement to discourse: Qualitative research and the crisis of legitimation. In Virginia Richardson (Ed.), Handbook of research on teaching (4th ed.). Washington, DC: AERA.

Oakes, J. (1985) Keeping track: How schools structure inequality. New Haven: Yale University Press.

Rex, L. A. (1997). Making a case: A study of classroom construction of academic literacy. Unpublished doctoral dissertation, University of California, Santa Barbara.

Rex, L., Green, J., \& Dixon, C. (1997). Making a case from evidence: Constructing opportunities for learning academic literacy practices. Interpretations, 30(2), 78-104.

Rex,L. A. (2001). The remaking of a high school reader. Reading Research Quarterly, 36(3), 288-314.

Rex, L., \& McEachen, D. (1999). "If anything is odd, inappropriate, confusing, or boring, it's probably important": The emergence of inclusive academic literacy through English classroom discussion practices. Research in the Teaching of English, 34(1), 65-129.

Rex, L. A., Murnen, T., Hobbs, J., \& McEachen, D. (2002). Teachers' Pedagogical Stories and the Shaping of Classroom Participation: "The Dancer" and "Graveyard Shift at the 7-11". American Educational Research Journal, 32(3). 
Santa Barbara Classroom Discourse Group. (1992). Do you see what we see? The referential and intertextual nature of classroom life. Journal of Classroom Interaction, 27(1), 29-36.

Spradley, J. P. (1980). Participant observation. New York: Holt Rinehart and Winston.

Spradley, J. P. (1979). The ethnographic interview. New York: Holt, Rinehart and Winston.

Strauss, A., \& Corbin, J. (1990). Basics of qualitative research: Grounded theory procedures and techniques. Thousand Oaks, CA: Sage.

Swartz, D. (1997). Culture and power. The sociology of Pierre Bourdieu. Chicago: University of Chicago Press.

Veroff, J., \& Destephano, A. (Eds.). (2002). Researching across difference. American Behavioral Scientist, 45(8). Thousand Oaks, CA; Sage.

White, H. (1981). The value of narrativity in the representation of reality. In J. T. Mitchell (Ed.), On narrative (pp. 1-24). Chicago: The University of Chicago Press. 